\title{
Characterization of Moisture Conservation Practices on Yield of Sorghum in Holte, Southern Ethiopia
}

\author{
Asrat Fikre* \\ Department of Natural Resource Management, Wolkite University, Ethiopia
}

Submission: May 01, 2020; Published: May 12, 2020

*Corresponding author: Asrat Fikre, Department of Natural Resource Management, Wolkite University, Ethiopia

\begin{abstract}
Water is the common medium for several life processes; it is very limited in semi-arid climatic zone for growth and development. A coping mechanism; water management includes understanding about the release pattern and storage of water by the soil. The emphasis given to the conservation practices in conserving and retaining moisture is very limited in semi-arid zone of southern Ethiopia. The aim of this study is to characterize the three conservation practices in relation to moisture with various soil depths. Erratic rain fall over the season makes harsh for growing vegetations. Indigenous conservation practice in the form of (mona, poteya and targa), trash line and stony with little straw were evaluated for their volumetric moisture content. SAS 9.2 version was used to analyze the data, for instance, there was statistically difference (P $\leq 0.05$ ) among conservation practices and there was statistically difference between indigenous and trash line conservation practices over the stony with little straw conservation practice over the growing period and depth intervals of the profile.
\end{abstract}

Keywords: Soil moisture; Moisture conservation practices; Soil depth

\section{Introduction}

Water is the common medium for several life processes, lifecycle cease in the absence of water. For instance, in plants, mobility of necessary materials in the plant tissue is hold by soil water. Consequently, water and soil are the primary requirements for the life and growth of plants. However, water availability in soils is restricted, and therefore, its conservation and utilization turn into an indispensable issue [1]. Water management includes understanding about the release pattern and storage of water by the soil. Soil moisture data can be used for water reservoir content and managing, early advice of deficiencies, irrigation planning, and crop yield estimation [1,2]. In the semi-arid area, soil moisture is an important water source for plant growth $[3,4]$ and soil moisture consumption rates were found to depend on vegetation types $[5,6]$.

A limited attention has been given to how soil depth and type of soil and water conservations variation in soil moisture is affected by environmental factors. As depth variations of soil moisture have important implications on agriculture [7-9] and soil erosion $[10,11]$, understanding its dynamic role will provide a scientific basis for the optimization of spatial allocation in the depth basis crop production efforts. Specifically, soil moisture is an important stable water source for vegetation in the semi-arid environment, understanding soil depth and conservation practices variation on soil moisture is fundamental for the possible optimization of plant growth.

Straw terracing is indigenous moisture conservation practice in the form of mona, poteya and targa construction by the farmers with letting of sorghum/maize stalk with the soil in the previous season [12]. Trash lines are created across the slope using previous seasons crop residues maize, sorghum stalks and other dead vegetative organic materials to control surface runoff, soil erosion and enhance infiltration. Besides, stony with little straw is practiced by farmers as moisture conservation for cultivating crops in stone/rock dominated land.

\section{Objectives}

This study emphasizes on characterization of the three conservation practices in relation to moisture with various soil depths. 


\section{Materials and Methods}

\section{Description of the study area}

Holte kebele is located in Derashe special woreda of southern nation's nationalities and peoples of Ethiopia. In doing so the study plots were demarcated with latitude longitude and altitude of $33.52^{0}-33.56^{0}, 62.52^{0}-62.98^{0}$ and $1141-1136$ ma.s.l. (above sea level) respectively. The area is located in the semi-arid climatic zone, erratic rainfall [12] of monthly total from April to July was $217.0 \mathrm{~mm}, 46.7 \mathrm{~mm}, 62.0 \mathrm{~mm}$ and $7.0 \mathrm{~mm}$ respectively. The soil texture in the three conservation types were clay, clay and loam on indigenous conservation practice, trash line and stony with little straw respectively. Water shortage is the major constraint to vegetation growth and agriculture production. The cropping system in study area is sparse alley cropping of either sorghum or maize with Acacia or Cordia Africana trees.

\section{Description of oil and water conservation practices in the study area}

For this study three plots with three soil and water conservation practices (indigenous conservation practices/straw terracing [12], trash line conservation practice and stony with little straw application) were considered. The first two conservations are the common practices and the last one is practiced in stony farms like as stone mulch by the peoples of Derashe. The aim of this study is to characterize three practiced soil and water conservation measures on soil moisture content and yield of sorghum in Holte area.

Farmers in semi-arid areas like holte are embracing practices that enhance agricultural productivity by conserving soil moisture. For instance, the local peoples have developed indigenous soil and water conservation practice called indigenous conservation practice in the form of (mona, poteya and targa) [12]. Mona is ridge developed for making the basin with the use of minimum tillage soil in the basin's catchment. Poteya is a rectangular structure called basin that enhance time of concentration of the runoff and Targa is a series of 3-5 poteyas, used as a barrier for flooding and facilitates to infiltration. These physical soil and water conservation structures integrated with straw provides good moisture and soil conservation in derashe area that were developed through their knowledge to cope the harsh condition like Konso terracing.

Trash lines are created across the slope using previous seasons crop residues maize, sorghum stalks and other dead vegetative organic materials to control surface runoff, soil erosion and enhance infiltration. Trash lines can be $1 \mathrm{~m}$ wide that is practiced by some farmers in the study area; where the sorghum / maize stalk is consumed as fuel wood.

Whereas, stony with little trash line conservation practice is commonly practiced in small rock dominated areas of conservation agriculture land, technically like stone terracing with applying of sorghum or maize stalk over the terrace (Figure 1).

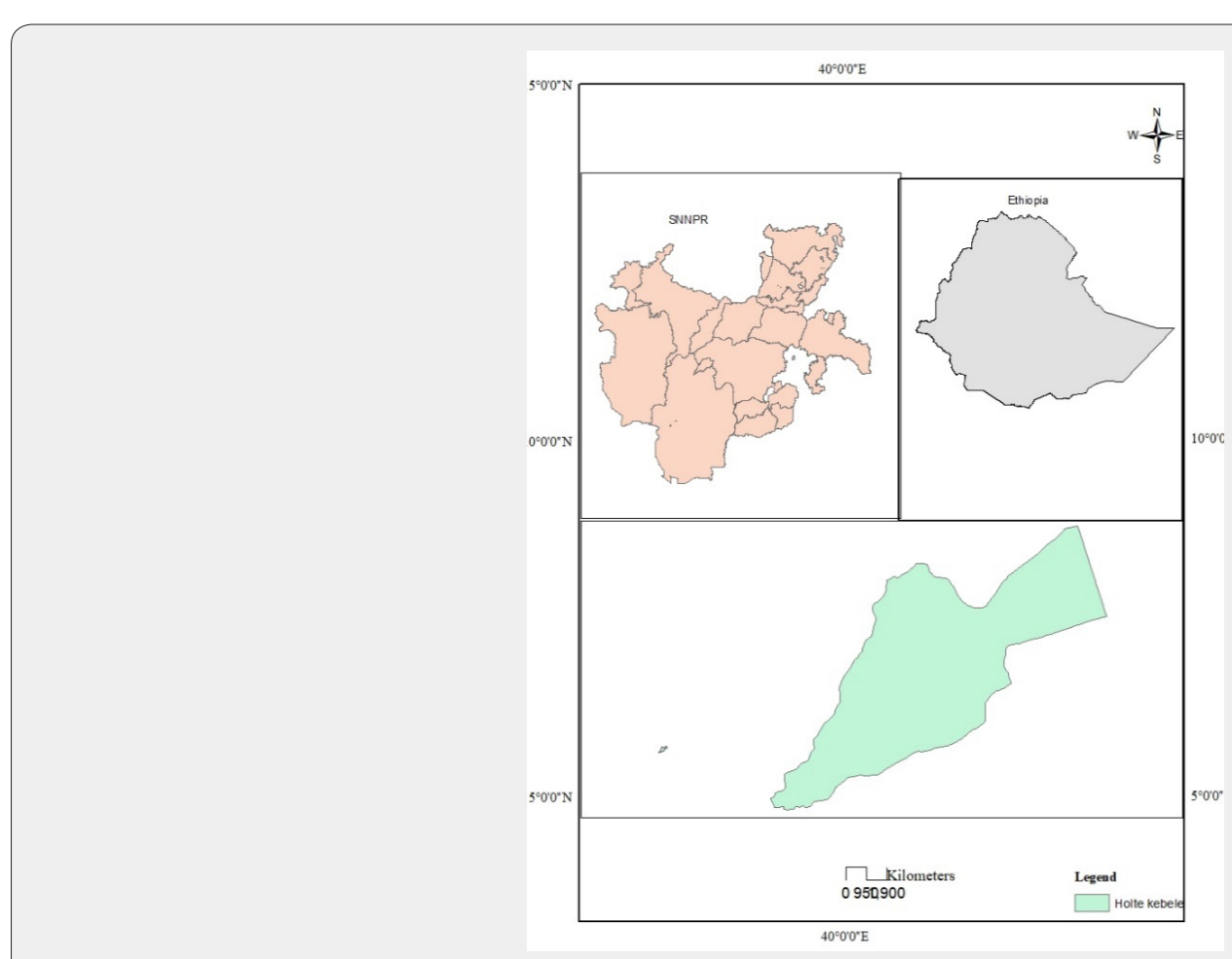

Figure 1: Map of the study area. 


\section{Soil moisture content measurement}

Soil moisture measurements in the growing seasons were made by opening the three profile pits from the surface layer to $90 \mathrm{~cm}$ in $30 \mathrm{~cm}$ intervals. Soil samples were taken by a moisture can and core sampler, and stored in sealed plastics when taken out. Then the sealed plastics were taken to laboratory to measure SMC (unit: gg $^{-1}$ ) by using gravimetric approach. The SMC was determined using the oven-dry method $(24 \mathrm{~h}$ at $105 \circ \mathrm{C})$. Three sampling profiles were purposefully chosen to obtain the SMC variation on rock dominated and other conservation lands with the use of trash line moisture conservation and one site with indigenous conservation practices. For every stratified depth interval $(30 \mathrm{~cm}$ for this study) three core sampler data were obtained on triangular basis for each layer, then the depthaveraged SMC of each profile pit at each layer was calculated as:

$$
\omega x=\frac{1}{j} \sum_{j=1}^{j} S M C_{j}
$$

where $\mathrm{j}$ is the number of sample measurements at each layer $\mathrm{x}$, and $\mathrm{SMC}_{\mathrm{j}}$ is the soil moisture content in layer $\mathrm{x}$ calculated by three sampling profiles. The number of measurement layers at each layer is 3 with the 3 layers $(0-30 \mathrm{~cm}, 31-60 \mathrm{~cm}$, and $61-90 \mathrm{~cm})$ in each profile and a total of 27 soil samples were collected from the three profiles.

Bulk density was determined by dividing dry weight of the bulk sample that was captured by the core sampler at categorized layer to volume of soil core. Then averaged bulk density was obtained for every layer and volumetric soil moisture content were determined by multiplying gravimetric moisture content and bulk density, while density of water is $1 \mathrm{~g} / \mathrm{cm}^{3}$.

$$
\begin{aligned}
& \delta b=\text { Dry } w^{\prime} t / \text { volume } \\
& \theta\left(\frac{\mathrm{cm}^{3}}{\mathrm{~cm}^{3}}\right)=\frac{\omega(g)}{g} * \delta b / \delta w
\end{aligned}
$$

$$
\begin{aligned}
& \text { Moisture }(\%)=\theta \times 100 \\
& \text { Where; } \delta b \text { is bulk density and } \delta w \text { is density } \\
& \text { of water, } \theta \text { is volumetric soil moisture content }
\end{aligned}
$$
$\delta b$ is bulk density and $\delta w$ is density of water, $\theta$ is volumetric soil moisture content

\section{Result and Discussion}

\section{Moisture content of the top $0-30 \mathrm{~cm}$}

According to the result stony plot with little straw retains a very little moisture than others. This is due to the rocky characteristics of the plot that have little soil to hold moisture. The indigenous conservation practice showed a vigorous retention capability (Figure 2).

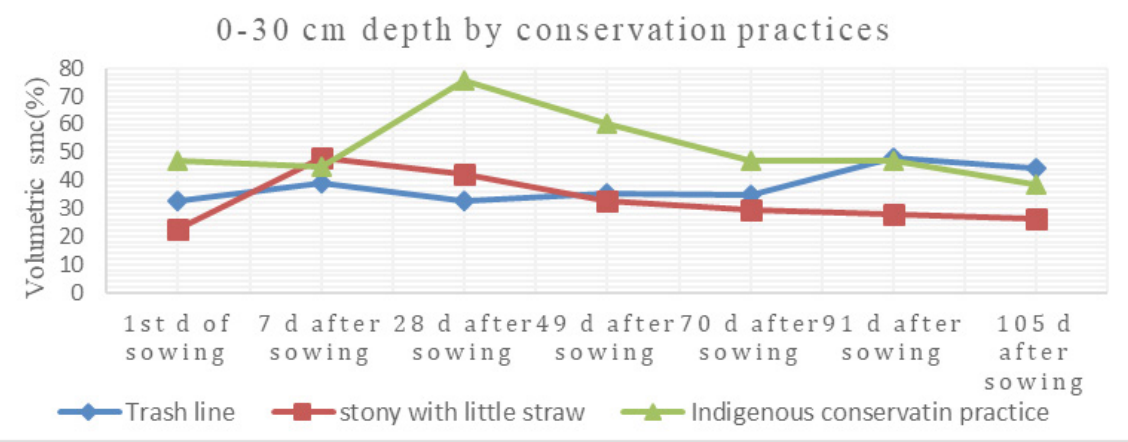

Figure 2: Moisture content over the conservation measures.

The result indicated that indigenous conservation practices increased significantly $(\mathrm{P} \leq 0.05)$ soil moisture contents at $0-30 \mathrm{~cm}$ as compared to trash line conservation practice and stony with little straw. This may due to better structured conservation practices (i.e., mona, poteya and targa) in retaining moisture and minimizing the evaporation from the soil pores by having of better mulch than the two practices. It is expected better retarding capacity of runoff and soil erosion. There was high surface cracking was observed due to following of long spell of dry weather after raining. The findings of the present study indicated that effectiveness of indigenous conservation practice as in-situ moisture conservation method was highly significant, which enabled rain water to be held on the surface of land and absorbed by the soil [12].

\section{Moisture content at middle $31-60 \mathrm{~cm}$ depth}

This moisture content was collected when the root of the crop grows larger and larger to take the moisture (i.e. root $>30 \mathrm{~cm}$ ). As observed from figure 2, moisture content by indigenous conservation practice was significant with the two. 
The analysis of variance revealed that soil moisture content determined at growing season of sorghum plant was significantly influenced by conservation practices used. It indicated that indigenous moisture conservation practices and trash line moisture conservation practices increased significantly $(\mathrm{P} \leq 0.05)$ soil moisture contents at $31-60 \mathrm{~cm}$ over stony with little straw. The average moisture content difference among indigenous conservation practices and trash line were 28 and $27 \%$ over stony with little straw respectively, this may be the little infiltration capacity of the stone dominated soil. But the variation between indigenous conservation practice and trash line was only $1 \%$. This was due to little exposure of the middle layer to evaporation.

\section{Moisture content of $61-90 \mathrm{~cm}$ depth}

The same to the middle depth of the soil profile, moisture content of $61-90 \mathrm{~cm}$ depth was significant with in conservation practices. It indicated that indigenous moisture conservation practices and trash line moisture conservation practices increased significantly $(\mathrm{P} \leq 0.05)$ soil moisture contents at $61-90 \mathrm{~cm}$ over stony with little straw.

Generally, the result reveals that indigenous moisture conservation practices and trash line moisture conservation practices increased significantly $(\mathrm{P} \leq 0.05)$ soil moisture contents of $61-90 \mathrm{~cm}$ over stony with little straw. The average moisture content variation between indigenous moisture conservation practices and trash line moisture conservation practices over stony with little straw were 21 and $31 \%$ respectively.

\section{The relationship of conservation practices with depth \\ in reference to moisture}

The result reveals that there was a positive relationship between conservation practices (between indigenous and trash line moisture conservation practices) with depth. This was due to less effect of evaporation on the deeper soil profile and less availability of moisture to roots of the plant at deeper horizon. However, stony with little straw plot showed decrement of moisture content as the soil depth increasing; this may be due to youngness of the profile to store moisture in the pores of the soil. Since stony with little straw plot, the surface has better soil particle composition to hold more moisture than the deeper. In general, the stony plot retains less soil moisture content than the two plots. The following figure showed the relationship in detail on indigenous conservation practices.

The three soil and water conservation practices in the case of Holte affect soil moisture, then improved soil water storage in the profile by enhancing infiltration which was important in increasing sorghum yield immediately in the given season. This study revealed that soil and water conservation practices markedly influences soil moisture at various depths. This result agreed with other studies $[12,13]$, reported on the significant responses of soil and water conservation practices to the high values of soil and runoff losses from an area of low and erratic rainfall in the semi-arid areas by retaining both soil and moisture and thereby increased productivity.

\section{Conclusion}

The volumetric soil moisture content of indigenous conservation practice (targa, poteya, mona) shows decrement from booting to harvesting. This was due to the long dry spell weather after 50 days after sowing to harvesting in the study area or high consumption of moisture by roots of the crop even at harvesting time. However, the leaves of sorghum during grain harvesting were green over the rest two practices. For this fact, harvesting time was delayed for five days. Indigenous conservation practice has great impact on moisture conservation over the other conservation practices. The relationship between soil depth and soil moisture content showed direct proportional in the two practices and inverse proportional with the stony dominated soil profile. Soil and water conservation methods can influence the moisture retained by the soil at various depths.

\section{References}

1. (2019) Gabriela Civeira Instituto Nacional de Tecnologia Agropecuaria, Hurlingham, Argentina: Introductory chapter-soil-moisture.

2. Briggs LJ (2016) The Mechanics of Soil Moisture Paperback. Wentworth Press, Australia, p. 38.

3. Lin H, Bouma J, Pachepsky Y (2006) Hydropedology: Bridging disciplines, scales and data. Geoderma 131(3-4): 255-240.

4. Cao S, Chen L, Yu X (2009) Impact of China's Grain for Green Project on the landscape of vulnerable arid and semi-arid agricultural regions: a case study in northern Shaanxi Province. J Appl Ecol 46(3): 536-543.

5. Wang Z, Liu B, Zhang Y (2009) Soil moisture of different vegetation types on the Loess Plateau. J Geogr Sci 19(707): 707-718.

6. Wang, Y, Shao, M, Shao H (2010b) A preliminary investigation of the dynamic characteristics of dried soil layers on the Loess Plateau of China. J Hydrol 381(1-2): 9-17.

7. Hebrard O, Voltz M, Andrieux P, Moussa R (2006) Spatiotemporal distribution of soil surface moisture in a heterogeneously farmed Mediterranean catchment. J Hydrol 329(1-2): 110-121.

8. L Yang, W Wei, L Chen, F Jia, B Mo (2012) Spatial variations of shallow and deep soil moisture in the semi-arid Loess Plateau. Hydrol Earth Syst Sci 16: 3199-3217.

9. Liu Y, Li S, Chen F, Yang S, Chen X (2010) Soil water dynamics and water use efficiency in spring maize fields subjected to different water management practices on the Loess Plateau, China. Agr Water Manage 97(5): 769-775

10. Chen L, Wei W, Fu B, Lu Y (2007b) Soil and water conservation on the loess plateau in China: review and perspective. Prog Phys Geogr 31(4): 389-403.

11. Fitzjohn C, Ternan JL, Williams AG (1998) Soil moisture variability in a semi-arid gully catchment: implications for runoff and erosion control. Catena 32(1): 55-70. 
12. Fikre A, Ayana M, Alaro A, Mamo G (2018) Evaluating effects of conventional practice and straw mulch applications on moisture conservation in semiarid Ethiopia. Environ Risk Assess Remediat 2(3): 8-13.
13. Wang L, Wei S, Horton R, Shao M (2011) Effects of vegetation and slope aspect on water budget in the hill and gully region of the Loess Plateau of China. Catena 87(1): 90-100.

Your next submission with Juniper Publishers will reach you the below assets

- Quality Editorial service

- Swift Peer Review

- Reprints availability

- E-prints Service

- Manuscript Podcast for convenient understanding

- Global attainment for your research

- Manuscript accessibility in different formats

( Pdf, E-pub, Full Text, Audio)

- Unceasing customer service

Track the below URL for one-step submission https://juniperpublishers.com/online-submission.php 
